\title{
TRADITIONAL VERSUS AGILE PROJECT MANAGEMENT IN PUBLIC SECTOR IN POLAND
}

\author{
Anna KACZOROWSKA \\ University of Lodz; anna.kaczorowska@uni.lodz.pl, ORCID: 0000-0003-4372-5637
}

\begin{abstract}
Purpose: In recent years more and more agile methods of software production have been used in information projects (IT projects). Apart from some common features with other measures, IT projects have their own specificity which should be considered prior to the choice of the Traditional Project Management (TPM) or Agile Project Management (APM) for management of a particular project. Owing to the specificity of the implemented projects the approach presented in agile methods is more and more frequently chosen and preferred both by the solutions providers and the clients. Furthermore, the use of one of the traditional or agile methods should be preceded by analysis of various types of conditions of the sector in which the public administration entity is functioning. Legal conditions, organizational and decisionmaking culture, project financing methods and maturity of teams and the whole organisation in the project management area, affect not only the choice of methods but also the final success of the project. The multicriterial analysis of limitations in information projects implementation in the public sector allowed identification of the most important recommendations within necessary changes. The article points out that agile methods will not entirely replace the traditional management of IT projects in the public sector, with the most effective approach being their harmonious coexistence.
\end{abstract}

Design/methodology/approach: The recommendation to use the TPM and APM approaches in Polish public administration entities was preceded by analysis of the most important legal acts for this purpose and comparison of the position of our country (or cluster to which Poland is qualified) in the acknowledged European study from the cycle of eGovernment Benchmark dating back to the years 2004-2018. Recommendations for implementation of IT projects in the public sector were supported by analysis of CHAOS reports dating back to 2012-2018 and $11^{\text {th }}$, $12^{\text {th }}$ and $13^{\text {th }}$ Annual State of Agile Reports respectively from 2016, 2017 and 2018. The article does not treat separately each of the best known methodologies and methodologies of confirmed effectiveness, but considers the shared philosophy of traditional or agile approach.

Findings: The development of e-government proceeds due to the implementation - from the private sector - of the form of management through the development of projects. Analysis of the position of the Polish e-government in the eGovernment Benchmark points to a high backwardness of the public sector in Poland as compared to other countries. The backwardness may be made up for through implementation of effective methods of IT project management. However, the choice of an agile method should be preceded by an analysis of specific achievable benefits and conditions which have to be fulfilled as they are necessary to achieve such benefits. The public sector conditions connected with the Public Procurement Law and 
informal limitations resulting, among other, from organisational and decisive culture will not allow, as for now, to fully use agile methods.

Originality/value: The public sector in Poland is the largest but at the same time the most difficult customer of services and products from the ICT sector in Poland. For a large purchaser of the ICT sector solutions the choice of the most effective project management method becomes a significant determinant of the project's success. In practice, there is no organization or project in which a methodology in its pure form could be used. Therefore, a given methodological approach has to be adjusted to the conditions of the sector in which the organisation is functioning and to a specific project.

Keywords: project management, IT project, public sector, traditional methodologies, agile methodologies.

Category of the paper: Research paper.

\section{Introduction}

Owing to introduction of the project management to the public administration sector the e-government development in Poland is possible, its pace depending on the State's reasonable investments in new ICT technologies, due to which coherent ICT systems may appear in this sector all over the country (Kaczorowska, 2013).

The main task of the public sector offices is rendering of public services. IT projects should be established in this sector primarily to assure availability of consecutive e-services and ICT systems owing to which they may be provided.

Public administration not only renders services but is also functioning in the legal regulations system. The causes of corrupt scandals, multibillion losses, loss of customers' faces, bankruptcies of national implementors, and complex IT projects should be searched for in the Public procurement law which determines how the public projects are implemented in Poland.

The public sector in Poland is the largest but at the same time the most difficult customer of services and products from the ICT sector in Poland. In recent years, the public procurement supported by EU funds constituted about $25 \%$ of the demand for ICT sector services (Ministry of Development, 2017).

For a large purchaser of the ICT sector solutions the choice of the most effective project management method becomes a significant determinant of the project's success.

Acknowledged standards and methods of project management and the tools supporting these processes were described in detail in national (Lubiarz, 2015; Trocki, 2012, 2017; Wysocki, 2013) and world literature (Apello, 2012; Cohn, 2010; Layton, 2012; Shaydulin, and Sybrandt, 2017; Wendler, 2014).

Traditional methods are based on the assumption that the customer from the beginning „knows what she/he wants” and can express it in clear, explicit and measurable requirements. However, due to the impossibility of fast response to the increasing dynamics of changes in the 
project and its environment they are not adopted to realities of IT projects implementation. Observance of all their procedures and rules may also significantly slow down the process of implementation of a given undertaking (Chmielarz, 2012).

Agility on the executory - project level was implemented in practice in numerous agile methodologies developed first for IT projects management.

The main project benefits obtained owing to the agile approach comprise: higher easiness of coping with variable priorities, reduced time to market, reduced project risk, better adjustment of IT objectives and clients of IT solutions, higher productivity of works and faster visibility of the project effects (VersionOne, 2016; CollabNet, and VersionOne, 2017, 2018).

However, the use of any of the agile methodologies does not guarantee the occurrence of the mentioned benefits in each project and translating them into a higher efficiency of the whole organisation. The choice of an agile method should be preceded by an analysis of specific achievable benefits and conditions which have to be fulfilled as they are necessary to achieve such benefits.

Agile methodologies require from the project participants such abilities as: self-organisation of teams, group undertaking of commitments and decisions, self-reliance, creativity, courage, higher involvement of the customer in current operational measures, close cooperation between the contracting authority and the contractor. These are elements of organizational climate and culture and not only of project culture. The use of an agile approach to project management in the public sector should also involve this aspect.

Public institutions applying for project funds use the only project management methodology recommended by the European Commission, known as the Project Cycle Management, hereinafter referred to as the PCM (European Commission, 2004). This traditional, free and systematically updated methodology should serve improvement of the project management and programmes co-financed by the EU, but mostly taking rational decisions by the EC employees who earmark and check the use of aid funds. The recommendations contained in the PCM are not suitable for direct, complete application because they are focussed on the project financing principles and thus pass over other extremely important processes of management of the measures.

Because of a higher and higher complexity of IT projects, the demand for a dynamic definition of the scope of works during the project implementation and the lack of possibilities to use the PCM methodology as the only one for management of IT projects, such an approach in the public sector is necessary in which the instability of requirements will not pose a problem and which assures transparency and sorting out of activities, where most important is the creative team work and as close cooperation between the Contracting Authority and the Contractor as possible. Such requirements may be met by agile methods dedicated to the IT project management. The studies indicate (Project Management Institute, 2017, 2018; Speed \& Function Team, 2017) that in the IT project management the hybrid methods should 
be applied, which usually combine the traditional methodology with preferred elements of agile methods.

The development of e-government proceeds due to the implementation - from the private sector - of the form of management through the development of projects. Therefore, the recommendation to use the TPM and APM approaches in Polish public administration entities was preceded by analysis of the most important legal acts for this purpose and comparison of the position of our country (or cluster to which Poland is qualified) in the acknowledged European study from the cycle of eGovernment Benchmark dating back to the years 2004-2018. Analysis of the position of the Polish e-government in this study (Kaczorowska, and Ciach, 2013; Capgemini et al., 2015, 2016, 2017, 2018) points to a high backwardness of the public sector in Poland, as compared to other countries (Table 1, Table 2 and Table 3 in the Appendix). The backwardness may be made up for through implementation of effective methods of IT project management.

Recommendations for implementation of the IT projects in the public sector were supported by analysis of CHAOS reports dating back to 2012-2018 and $11^{\text {th }}, 12^{\text {th }}$ and $13^{\text {th }}$ Annual State of Agile Reports respectively from 2016, 2017 and 2018.

Agile methods are common in public sector in the USA, Canada and also Western Europe. Predominance of agile methods over traditional ones in ICT is also noticeable in implementation of European public procurement (Kański, 2018). Positive experience of other states confirms the possibilities of practical use of agile methods during implementation of the public sector projects in Poland.

\section{Key determinants of the success of IT projects in the context of application of agile methods}

The Standish Group which develops the CHAOS reports every year revised the project's success deviating from the ,golden triangle of the project parameters" defined by the Project Management Institute as the project implementation according to the budget, schedule and business requirements. The success measurement was enriched with the quality criteria and the client's satisfaction.

According to CHAOS reports (the Standish Group, 2012, 2014, 2015) both in 2012 (projects base dating back to 2002-2010), 2015 (projects of the years 2011-2015), 2016 (Johnson, and Mulder, 2016), and 2017/2018 (Lynch, 2018) the chances of the project's success obviously decrease with increased size of the project and its complexity. The percentage of large projects with a successful ending is only $2 \%$. In the public sector the lowest percentage $(21 \%)$ of successfully ended projects was noted. Such statistics induce to searching for new, advanced methods of implementation of the projects, increasing the chances for their success. 
The success of the project implementation was largely due to the agile method with which it was conducted - as many as 28 percentage points of the difference as compared to the management by traditional methodologies (the Standish Group, 2015).

At the same time the studies confirm that no matter what the scale of the project is, the use of an agile method supports achievement of success. Furthermore, they point to a strong dependence between the scale of implemented projects, adopted methodology of project management and probability to achieve success. This is particularly visible in long-lasting projects of a medium and high scale, where the use of agile methodologies of project management increases the probability to achieve success from 400 to $600 \%$, as compared to the use of traditional cascade methodologies (the Standish Group, 2015). Therefore, searching for the ways and possibilities of implementation of agile methods for project management is justified.

Classical methods do not include the process of erosion of the requirements formulated during the pre-implementation analysis. Presently, the outdating time of a half of the requirements reaches approx. 6 months (Atkinson, and Benefield, 2013). Implementation of the submitted IT projects having the nationwide and multimillion or even several billion budgets, lasts even several years in the public sector. Although formally the project was implemented pursuant to the assumed requirements, actually it ends with a defeat because of outdated functionalities which it supplies. An undeniable asset of agile methodologies is their faster response to the dynamics of changes in the measure's business environment (Project Success in Agile Development Projects,2017; Jeremiah, 2017).

Analysis of the key determinants of the IT project success induces us to pay attention to another significant relation in the context of the use of agile methods in implementation of projects in the public sector. The Annual State of Agile Reports (VersionOne, 2016; CollabNet, VersionOne 2017, 2018) indicates that the higher the involvement of agility factors which can be used in a given project, the higher the chance of its successful implementation. This trend is stronger in implementation of large, complex, and long-term projects. Although the use of not all attributes of agility of a given method increases the probability of the project's success, yet it does not enable a thorough use of its assets.

A success of the information project depends also on behavioural conditions of the project's participants, i.e. factors other than methodological and legislative (Dorsey, 2015).

\section{Conditions of IT projects implementation in the public sector}

Owing to the Act on information technology for the activities of the entities implementing the public tasks of 17 February 2005 (Act on information technology for the activities of the entities implementing the public tasks, 2005) in the public sector it is possible to set up projects, 
including IT projects, officially. In the first project in the history of Poland, Plan of the State's Informatization for the year 2006 (Decree of the Ministry Cabinet on the State's Informatization Plan for the year 2006, 2006) 6 IT projects were singled out (3 extra sectoral and 3 sectoral).

Implementation of all public projects, including IT projects, is financed by public means and is based on two legal acts: Act of 29 January 2004 Public Procurement Law hereinafter referred to as the PPL (Public procurement law, 2004) and the Act on public finances (Act on Public Finances, 2009). Unfortunately, the highest number of limitations and difficulties in implementation, especially of the biggest public projects (such as the construction and development of the Complex Information System of the Social Insurance Company, e-PUAP platform), results from the PPL (Public Procurement Law) provisions.

Achievement of success in each project depends on the offeror's skills in project management. Meanwhile, the national Public procurement law demands specification of the object of order according to European, international or Polish standards, but it does not demand any description of the offerors qualifications within the project management. This yields a high probability of the choice of a company which will not cope with implementation of a huge project or will cause the choice of a foreign contractor who does not know Polish conditions.

Legitimisation of the requirement that project managers must have certificates confirming their management skills consistent with any of the acknowledged methods is insufficient, because they may undertake activities exclusively within the procedures of the public administration entity for which they work.

The most important restrictions resulting from the currently applicable PPL (Public Procurement Law) are:

- requirement to have for each type of works a complete specification of their scope as early as at the moment of signing the contract;

- lack of the possibility to continuously adjust the scope of works to the changing circumstances (mechanism of ,additional orders" functioning in the PPL allows to supplement the set of works only in strictly specified conditions);

- negligence to include - in the PPL - the risks which may occur during implementation of a given project;

- nonoptimal set of tasks for the Public Procurement Office (PPO) in the aspect of enabling an efficient implementation of public projects.

Amendments to the PPL from 2016 ("Act of 22 June 2016 about the change of the Public Procurement Law and some other acts, 2016) and 2018 (Act of 20 July 2018, changing the act - Public procurement law and the act on changing the Public Procurement Law and the act about the change of the Public Procurement Law and some other acts, 2018) provide for the mechanisms which allow to implement the IT projects in the public sector according to agile methods. In the context of the possibilities to use agile methods during IT projects implementation, the most important changes introduced by these amendments are: 
- extension of the scope of allowable changes in the agreement;

- innovative partnership as a new procedure to grant public procurement;

- requirement of electronic communication between the Contracting Authority and the contractor;

- using in a larger scope the capacity and functional criteria to prepare the tender documentation (TOR, PPS);

- mechanisms which enable closing of the parties' cooperation, combined with the so-called peaceful exit plans.

A significant limitation for promotion of agile methods of project management in public sector are competencies and preparations for correct evaluation of the proceedings aimed at granting of public procurement by legislative bodies (National Appeal Chamber - KIO, courts of general jurisdiction) and inspection bodies (Public Procurement Office). Evaluation of a possible appeal by the National Appeal Chamber when the public procurement proceedings involve the mechanisms allowing to use agile methods, requires from those who recognize such a possibility the legal protection with relevant knowledge supported by practice within the description of projects implemented according to agile methods.

Implementation of public procurement using agile methods of project management also arouses some fear of employees of the implementing authorities, connected with the lack of possibilities to use the known and common patterns of preparing and conducting the proceedings.

The project of a consecutive amendment of the Public Procurement Law, accepted by the government on 9 July 2019, makes it possible to use agile methods in national proceedings below the EU thresholds. Unfortunately, for public procurement above the EU thresholds, which usually refers to the IT projects on nationwide scale, the formalism in procedures is to be even higher. The realistic date when the new provisions of the Public Procurement Law will become valid is the 1 st of January 2021.

\section{Recommendations for implementation of IT projects in the public sector}

Among the recommendations which increase the chances and possibilities to use agile methods in IT project management, the change of internal procedures of the contracting authority within purchase and contracting is of key importance. What is most needed is the departure from the model of one-time, long-term orders for IT solutions and replacing it with shorter, modular projects.

The ability to implement projects by the company as a whole should be a priority criterion of choosing the contractors for the biggest projects in the public sector (Gasik, 2013). In evaluation of the companies competencies within the projects management the public sector 
could use the project maturity models (which determine the level of advancement of the organisation as a whole in project implementation), such as the Capability Maturity Model Integration or the Organizational Project Management Maturity Model (Juchniewicz, 2009; Juchniewicz, 2012). In the USA only the companies exhibiting a high project maturity level have a chance to obtain orders in governmental agencies tenders.

Changes in the bids evaluation criteria are also necessary. Evaluation should be conducted according to a more comprehensive scope of capacity, quality and functional criteria, such as the prototype of a part of the system, presentation of functionality, specification of functionalities which were awarded with bonuses.

Amendments to the Public Procurement Law should enable the dynamic definition of the scope of works during the project implementation. While drawing up the Terms of Reference (TOR) the Contracting Authority should describe the public procurement subject (PPD) in as precise a way as possible at a given stage. We should be aware from the very beginning that the Terms of Reference will undergo changes and ongoing specification. It is important that the changes in agreements entries refer not only to the possibility of a more comprehensive modification of the subject of order during the project implementation but that they also involve the peaceful scenarios of departure.

Modifications are needed within the tender documentation, including among other the use of such mechanisms as the Request for Information, Request for Quote, and Request for Proposal.

In the case of huge countrywide projects we should assume in advance that risks will appear. The lack of the preliminary estimation of risks on the part of the Contracting Authority from the public sector deprives the potential contractors from the IT branch of important knowledge about the realities of implementation of the future project. A more comprehensive popularisation of the innovative partnership will surely counteract the Contracting Authority's passivity, which is caused by the transfer of risk and responsibility to the contractor.

The TOR should be supplemented not only with a list of risks threatening the project but also with indication for which risks the Contracting Authority is responsible, for which the contractor is responsible, and for which risks the responsibility rests jointly with these participants of the project process. The risks connected with direct project management, among others those resulting from cooperation with sub-suppliers, should rest exclusively with the contractor. The list of risks included in the TOR would be specified by the Contracting Authority and would be elaborated by the contractor within the submitted bid. The contractor would be also obliged to estimate the consequences of all identified risks for the budget and schedule of the works. Leaving the responsibility for risks almost wholly on the part of the contractor will probably cause the situation where reasonable offerors will try to include their cost in the price which they propose themselves. The risks servicing cost should constitute a separate part of the offer's budget launched when a given risk occurs. 
The choice of a bid of lower costs as compared to those assumed in the budget by the Contracting Authority creates a possibility to finance the works which were not presented in the schedule of works from the difference between the reserved budget and the chosen cheaper offer. On the other hand, to take an opportunity of the effect of earlier use of IT solution important for a given entity, the money obtained from the difference between the contractor's offer price and the predicted budget of the project could be used for a special financial bonus for the contractor for acceleration of the end of the work by a fixed period of time. Another requirement is implementation of motivating instruments, including financial ones, for the Contracting Authority's institution workers. These instruments should depend, among others, on the results of the project.

The Public Procurement Office, as the central institution most directly involved in public projects implementation, especially in the largest projects, should:

- determine the project management standards and the ways of evaluation of the contractors' relevant competences (at best according to the project maturity model), and supervise their subsequent use;

- participate (together with representatives of the Contracting Authority and the selected contractor) in project's steering committees; a highly qualified representative of the Public Procurement Office would be responsible for adjudication of any possible disputes between the Contracting Authority and the contractor and participation in approval of work and specification of changes;

- participate in the tender process and consequently support those submitting the orders (not all organisations using the public tenders have sufficiently qualified staff within the project management);

- provide the consultancy for the contractors within the projects management organisation and conduct a register of companies capable of project implementation (however, the minus of this proposal is impeding free competition); such solution is used in Great Britain, New South Wales and Canada.

For better coordination of the activities of all parties of the proceedings and to reduce the incompetence of other participants of the proceedings (legal protection bodies and the second instance bodies) to grant the public procurement in the IT projects area, a coherent series of training courses on project management with preferred agile methods should be provided.

Considering that a higher use of the agility attributes in the project increases the probability of success, an important issue is searching for the ways and possibilities to implement the maximum amount of agile factors in projects. 


\section{Summary}

Failures connected with implementation of national information projects have their source mostly in the Public procurement law. First, a complex analysis of the Polish public procurement system involving the best world solutions is required. Next, the Public procurement law should be reconstructed thoroughly and comprehensively, not just temporarily and fragmentarily.

There are no precise studies pointing that a chosen method, whether traditional or agile, is better than other methods. In practice, there is no organization or project in which a methodology in its pure form could be used. Therefore, a given methodological approach has to be adjusted to the conditions of the sector in which the organisation is functioning and to a specific project. For example in public administration entities implementing the SCRUM method, the product owner will surely be not just one person but the whole team of experts which has to be treated as one entity.

In few Polish offices the management is conducted pursuant to APM principles. This usually requires bending of the APM principles to one's own needs and being creative. For example, the Organization Department at the Marshal's Office of Silesian voivodeship (MOSV) provides the development and support of the Local Information System using the SCRUM method. This is the biggest of all similar systems functioning in other voivodeships. Entrusting the developmental works to one of the departments of the MOSV instead of concluding a contract with an external company results in that new needs do not have to be formulated in form of the POD and wait for the tender decisions. Every new idea is worked out from the beginning by the Organizing Department, it has a chance to change and is handed over without unnecessary formalities. In the traditional model of the information system development all procedures would run in cascades: first the more or less complex needs would be collected, which would then be gathered into one big order. Subsequently, if a contractor was selected, it would occur in turn: implementation, tests, reception and implementation. In practice, this could mean that for an insignificant functionality one would have to wait as long as a few months. Owing to the use of the agile method, the effects are visible very fast, therefore there is a possibility to back out of inaccurate ideas, incurring relatively insignificant losses.

Presently, the most effective approach seems to be the combination of the Project Cycle Management methodology and selected practices derived from agile methods, however as it is proposed to be used for ,the customer who does not belong to the group of most agile projects to manage", one should be aware that to obtain effects from the use of the approach it becomes necessary to employ more management staff which will trust the possibilities of selforganization of agile project teams and higher creativity of the public administration employees. 
The public sector conditions connected with the Public Procurement Law and informal limitations resulting, among others, from organisational and decisive culture will not allow, as for now, to fully use agile methods.

Complete use of preferred agile methods for implementation of IT projects in the public sector in Poland will not be an easy or short process. However, this task has to be undertaken to benefit from the use of this group of methodologies. After all, effective approach to project management is expected, appreciated and more and more frequently perceived as an instrument to construct the organisation's value.

\section{References}

1. A look at 25 years of software projects. What can we learn? Available online https://speedandfunction.com/look-25-years-software-projects-can-learn/, 2019.06.10.

2. Aid Delivery Methods - Project Cycle Management Guidelines Vol 1 - Guidelines. Available online https:/ec.europa.eu/europeaid/sites/devco/files/methodology-aiddelivery-methods-project-cycle-management-200403_en_2.pdf, 2019.06.15.

3. Apello, J. (2012). How to Change the World: Change Management 3.0. Rotterdam: Kindle Edition.

4. Atkinson, S., and Benefield, G. Software Development: Why the Traditional Contract Model Is no Fit for Purpose. Retrieved from https://static1.squarespace.com/ static/52c7ec69e4b0b1 f6fe574925/t/52cbe684e4b09298835e74ae/1389094532520/HICSS -2013-Why-the-traditional-contract-is-not-fit-for-purpose.pdf, 2019.06.15.

5. Capgemini, IDC, Sogeti, Politecnico di Milano (2015). Future-proofing eGovernment for a Digital Single Market. Retrieved from https://www.capgemini.com/resources/full-reportfuture-proofing-egovernment-for-a-digital-single-market/.

6. Capgemini, IDC, Sogeti, Politecnico di Milano (2016). A turning point for eGovernment development in Europe? Retrieved from http://publications.europa.eu/resource/cellar/ b3627b36-b212-11e6-871e-01aa75ed71a1.0001.01/DOC_1.

7. Capgemini, IDC, Sogeti, Politecnico di Milano (2017). Taking stock of user-centric design and delivery of digital public services in Europe. Retrieved from https://www.capgemini.com/wp-content/uploads/2017/11/2017-egovernmentbenchmark_background_v7.pdf.

8. Capgemini, IDC, Sogeti, Politecnico di Milano (2018). Securing eGovernment for all. Retrieved from https://ec.europa.eu/information_society/newsroom/image/document/ 2018-47/egovernment_benchmark_2018_background_report_F21FA84B-0254-F4DB7B2FC4567D4AA925_55487.pdf. 
9. CHAOS MANIFESTO 2012: The Year of the Executive Sponsor. Available online https:/cs.calvin.edu/courses/cs/262/kvlinden/resources/CHAOSManifesto2012.pdf.

10. CHAOS REPORT 2015. Available online https:/www.standishgroup.com/sample research_files/CHAOSReport2015-Final.pdf, 2019.06.12.

11. CHAOS REPORT: $21^{\text {st }}$ Anniversary Edition. Available online https://www.standishgroup.com/sample_research_files/CHAOSReport2014.pdf, 2019.06.10.

12. Chmielarz, W. (2012). Kryteria wyboru metod zarządzania projektami informatycznymi. Problemy Zarzadzania, 10(3), 25-40. doi: 10.7172.1644-9584.38.2.

13. Cohn, M. (2010). Succeeding with Agile: Software Development Using Scrum. Boston: Addison-Wesley Professional.

14. CollabNet, VersionOne. $12^{\text {th }}$ annual state of agile ${ }^{\text {tm }}$ report. Available online https://www.stateofagile.com/\#ufh-i-423641583-12th-annual-state-of-agile-report/473508, 2019.06.12.

15. CollabNet, VersionOne. $13^{\text {th }}$ annual state of agile ${ }^{\text {tm }}$ report. Available online https://www.stateofagile.com/\#ufh-i-521251909-13th-annual-state-of-agile-report/473508, 2019.06.13.

16. Dorsey, P. 10+3 główne powody, dla których projekty systemów się nie udaja. Czesść I. Retrieved from https://zarzadzanieprojektami.org/warsztat/10-3-glowne-powody-dlaktorych-projekty-systemow-sie-nie-udaja-czesc-i_338, 2019.06.15.

17. Dorsey, P. 10+3 główne powody, dla których projekty systemów się nie udają. Część II. Retrieved from https://zarzadzanieprojektami.org/warsztat/10-3-glowne-powody-dlaktorych-projekty-systemow-sie-nie-udaja-czesc-ii_343, 2019.06.15.

18. Gasik, S. Dlaczego nie udaja sie wielkie projekty publiczne? Retrieved from https://zarzadzanieprojektami.org/warsztat/dlaczego-nie-udaja-sie-wielkie-projektypubliczne-_332, 2019.06.10.

19. Jeremiah, J. Agile vs. waterfall: Survey shows agile is now the norm. Retrieved from $\mathrm{https}$ ://techbeacon.com/survey-agile-new-norm, 2019.06.14.

20. Johnson, J., and Mulder, H. (2016). CHAOS Chronicles, focusing on failures and possible improvements in IT projects. SYSTEMICS, CYBERNETICS AND INFORMATICS, 14(5), 11-15. Retrieved from http://www.iiisci.org/journal/CV\$/sci/pdfs/SA136MM16.pdf, 2019.06.11.

21. Juchniewicz, M. (2012). Dojrzałość projektowa organizacji. In: M. Trocki (Ed.), Nowoczesne zarzadzanie projektami (pp. 372-386). Warszawa: PWE.

22. Juchniewicz, M. (2009). Dojrzałość projektowa organizacji. Warszawa: Bizarre.

23. Kaczorowska, A. (2013). E-ustugi administracji publicznej w warunkach zarzadzania projektami. Łódź: Wydawnictwo Uniwersytetu Łódzkiego.

24. Kaczorowska, A., and Ciach, K. (2013). The effectiveness of e-government development in Poland in 2004-2013. Information Systems in Management, 2(4), 274-288. 
25. Kański, Ł. (2017). Prawne i organizacyjne uwarunkowania implementacji zwinnych metod zarządzania projektami IT. Organizacja i Zarzadzanie: kwartalnik naukowy, 2, 27-45. Retrieved from http://yadda.icm.edu.pl/yadda/element/bwmeta1.element.baztechc2c85401-5410-4bd1-830a-7b714f5a8535, 2019.06.14.

26. Layton, M. (2012). Agile Project Management. New Jersey: John Wiley\&Sons Ltd.

27. Łubiarz, M. (2015). Zwinne organizacje. Zarzadzanie projektami, 1(8), 87-91.

28. Lynch, J. (2018). Project Resolution Benchmark Report. Retrieved from https://www.standishgroup.com/sample_research_files/DemoPRBR.pdf, 2019.06.11.

29. Ministerstwo Rozwoju (2017). Perspektywy rozwoju polskiej branży ICT do roku 2025. Warszawa: Polska Agencja Rozwoju Przedsiębiorczości.

30. PMI. Pulse of the Profession 2017. $9^{\text {th }}$ Global Project Management Survey. Retrieved from https://www.pmi.org/-/media/pmi/documents/public/pdf/learning/thoughtleadership/pulse/pulse-of-the-profession-2017.pdf, 2019.06.14.

31. PMI. Pulse of the Profession 2018. $10^{\text {th }}$ Global Project Management Survey. Retrieved from https://www.pmi.org/-/media/pmi/documents/public/pdf/learning/thoughtleadership/pulse/pulse-of-the-profession-2018.pdf, 2019.06.14.

32. Project Success in Agile Development Projects. Available online https://arxiv.org/ ftp/arxiv/papers/1711/1711.06851.pdf, 2019.06.15.

33. Rozporządzenie Rady Ministrów w sprawie Planu Informatyzacji Państwa na rok 2006, Dz.U. nr 147, poz. 1064 (2006).

34. Shaydulin, R., and Sybrandt, J. To Agile, or not to Agile: A Comparison of Software Development Methodologies. Retrieved from https://www.researchgate.net/publication/ 316471308_To_Agile_or_not_to_Agile_A_Comparison_of_Software_Development_Met hodologies, 2019.06.10.

35. Trocki, M. (2012). Nowoczesne zarzadzanie projektami. Warszawa: PWE.

36. Trocki, M. (2017). Metodyki i standardy zarzadzania projektami. Warszawa: PWE.

37. Ustawa z dnia 17 lutego 2005 r. o informatyzacji podmiotów realizujących zadania publiczne, Dz.U. nr 64, poz. 565 z późn. zm. (2005).

38. Ustawa z dnia 20 lipca 2018 r. zmieniająca ustawę - Prawo zamówień publicznych oraz ustawę o zmianie ustawy - Prawo zamówień publicznych oraz niektórych innych ustaw, Dz.U. poz. 1603 (2018).

39. Ustawa z dnia 22 czerwca 2016 r. o zmianie ustawy Prawo zamówień publicznych oraz niektórych innych ustaw, Dz.U. poz. 1020 (2016).

40. Ustawa z dnia 27 sierpnia 2009 r. o finansach publicznych, Dz.U. nr 157, poz. 1240 z późn. zm. (2009).

41. Ustawa z dnia 29 stycznia 2004 r. Prawo zamówień publicznych, Dz.U. nr 19, poz. 177 z późn. zm. (2004). 
42. VersionOne. $11^{\text {th }}$ annual state of agile ${ }^{\text {tm }}$ report. Available online http://www.agile247.pl/ wp-content/uploads/2017/04/versionone-11 th-annual-state-of-agile-report.pdf, 2019.06.11.

43. Wendler, R. (2014). Develompent of the Organizational Agility Maturity Model. Proceedings of the 2014 Federated Conference on Computer Science and Information Systems, 2, 1197-1206. doi: 10.15439/2014F79.

44. Wysocki, R. (2013). Efektywne zarzadzanie projektami. Tradycyjne, zwinne, ekstremalne. Gliwice: Helion. 


\section{Appendix}

\section{Table 1.}

20 common public services in Poland in the rankings of eGovernment covering the years 2004-2010

\begin{tabular}{|c|c|c|c|}
\hline $\begin{array}{c}\text { THE YEAR OF } \\
\text { THE REPORT } \\
\text { PREPARATION }\end{array}$ & $\begin{array}{c}\text { POLAND'S POSITION } \\
\text { IN VIEW OF FULL } \\
\text { ONLINE } \\
\text { AVAILABILITY OF } \\
\text { SERVICES }\end{array}$ & $\begin{array}{c}\text { POLAND'S POSITION } \\
\text { WITH REGARDS TO } \\
\text { SERVICES } \\
\text { MATURITY }\end{array}$ & $\begin{array}{c}\text { NUMBER OF STATES } \\
\text { PARTICIPATING IN } \\
\text { THE STUDY }\end{array}$ \\
\hline 2004 & 26 & 27 & 28 \\
\hline 2006 & 25 & 26 & 28 \\
\hline 2007 & 30 & 30 & 31 \\
\hline 2009 & 25 & 24 & 31 \\
\hline 2010 & 19 & 20 & 32 \\
\hline
\end{tabular}

Source: Own preparation on the basis of "The effectiveness of e-government development in Poland in 2004-2013” by A. Kaczorowska, and K. Ciach. 2013 by SGGW Publishing House.

Five clusters (neophytes, high potential, progressive, builders and mature) and also five groups (with similar national context) have been identified in the eGovernment Benchmark reports from the years 2012-2016. It made it possible to determine eGovernment maturity within countries and to identify different clusters of countries with similar eGovernment maturity performance. In 2012-2016 Poland was always qualified to the progressive cluster and Group 2 (Table 2). Countries in this cluster have been working on a digital approach, but there are some factors that constrain full distribution of satisfying eGovernment services and the progressive cluster should focus on removing those barriers. Policies and innovation plans in countries from this cluster should specifically address and support deployment of a citizencentric approach to further increase the use of eGovernment services.

Table 2.

Poland and other countries from progressive cluster and Group 2 in the eGovernment Benchmark from the years 2012-2016

\begin{tabular}{|c|c|c|}
\hline $\begin{array}{c}\text { YEARS } \\
\text { INCLUDED IN } \\
\text { THE STUDY }\end{array}$ & $\begin{array}{c}\text { COUNTRIES FROM THE PROGRESSIVE } \\
\text { CLUSTER AND GROUP 2 }\end{array}$ & $\begin{array}{c}\text { NUMBER OF STATES } \\
\text { PARTICIPATING IN THE } \\
\text { STUDY }\end{array}$ \\
\hline $2012-2013$ & Germany, Italy, Poland, Spain & 32 countries named EU-27+ \\
\hline $2013-2014$ & Germany, Italy, Poland, Spain & 32 countries named EU-27+ \\
\hline $2014-2015$ & Germany, Italy, Poland, Spain & 33 countries named EU-28+ \\
\hline
\end{tabular}

Source: Own preparation on the basis of "eGovernment Benchmark 2016". 2016 by Publications Office of the European Union.

Four clusters/scenarios (Unexploited eGov, Fruitful eGov, Non-consolidated eGov, Expandable eGov ) have been identified in the eGovernment Benchmark reports from the years 2017-2018. Countries' eGovernment performance was measured through the absolute indicators, i.e. Penetration and Digitisation. Both of these indicators have three-stage scales: LOW, MEDIUM, HIGH. In 2017-2018 Poland was qualified to the Non-consolidated eGov group (Table 3). This scenario contains a lower level of Digitisation and a lower level of 
Penetration (understood as the extent to which the use of the online channel is widespread among users of government services).

Table 3.

Poland and other countries from Non-consolidated eGOV cluster taking into account Penetration and Digitalisation in the eGovernment Benchmark from the years 2017-2018

\begin{tabular}{|c|c|c|c|c|}
\hline $\begin{array}{l}\text { YEARS } \\
\text { INCLUDED } \\
\text { IN THE } \\
\text { STUDY }\end{array}$ & $\begin{array}{c}\text { COUNTRIES } \\
\text { FROM THE NON- } \\
\text { CONSOLIDATED } \\
\text { EGOV CLUSTER }\end{array}$ & PENETRATION & DIGITALISATION & $\begin{array}{c}\text { NUMBER OF } \\
\text { STATES } \\
\text { PARTICIPATING } \\
\text { IN THE STUDY } \\
\end{array}$ \\
\hline 2016 & $\begin{array}{c}\text { Bulgaria } \\
\text { Hungary } \\
\text { Greece } \\
\text { Luxembourg } \\
\text { Slovenia } \\
\text { Poland } \\
\text { Cyprus } \\
\text { Czech Republic } \\
\text { Italy }\end{array}$ & $\begin{array}{c}\text { MEDIUM } \\
\text { LOW } \\
\text { LOW } \\
\text { MEDIUM } \\
\text { MEDIUM } \\
\text { On the border } \\
\text { LOW MEDIUM } \\
\text { MEDIUM } \\
\text { LOW } \\
\text { LOW }\end{array}$ & $\begin{array}{c}\text { LOW } \\
\text { LOW } \\
\text { LOW } \\
\text { MEDIUM } \\
\text { MEDIUM } \\
\text { MEDIUM } \\
\text { MEDIUM } \\
\text { MEDIUM } \\
\text { MEDIUM }\end{array}$ & $\begin{array}{c}34 \text { countries named } \\
\text { EU-28+ }\end{array}$ \\
\hline 2017 & $\begin{array}{c}\text { Croatia } \\
\text { Bulgaria } \\
\text { Hungary } \\
\text { Greece } \\
\text { Slovakia } \\
\text { Luxembourg } \\
\text { Slovenia } \\
\text { Cyprus } \\
\text { Poland } \\
\text { Germany } \\
\text { Czech Republic } \\
\text { Italy }\end{array}$ & $\begin{array}{l}\text { MEDIUM } \\
\text { MEDIUM } \\
\text { MEDIUM } \\
\text { LOW } \\
\text { MEDIUM } \\
\text { MEDIUM } \\
\text { MEDIUM } \\
\text { MEDIUM } \\
\text { MEDIUM } \\
\text { MEDIUM } \\
\text { LOW } \\
\text { LOW }\end{array}$ & $\begin{array}{c}\text { LOW } \\
\text { LOW } \\
\text { LOW } \\
\text { LOW } \\
\text { MEDIUM } \\
\text { MEDIUM } \\
\text { MEDIUM } \\
\text { MEDIUM } \\
\text { MEDIUM } \\
\text { MEDIUM } \\
\text { MEDIUM } \\
\text { MEDIUM }\end{array}$ & $\begin{array}{c}34 \text { countries named } \\
\text { EU-28+ }\end{array}$ \\
\hline
\end{tabular}

Source: Own preparation on the basis of "eGovernment Benchmark 2017, 2018". 2017, 2018 by Publications Office of the European Union. 